\title{
蒸熱条件の違いによる茶葉色の変化
}

第 2 報 蒸熱時間の長短と茶葉色

福岡県農業総合試験場茶業指導所

大森薰・ 中村晋一郎・渡 辺 敏 朗

\section{Changes in Color of a Tea Leaf Steamed under Different Steaming Conditions}

\section{2) Effect of Steaming Time}

\section{By Kaoru OHmori, Shinichiro Nakamura and Toshiro Watanabe \\ Tea Branch, Fukuoka Agricultural Research Center}

\section{1 ま がき}

丞熱工程は煎茶製造における第 1 工程であり，その適 否は粗揉工程以降の揉乾操作の難易に関係するととも に，製茶品質にも大きな影響を与兄る。

現在, 蒸熱程度は蒸葉の色沢, 硬軟度並びに香気で総 合評価しているが，感覚的なるのだけに適確に判定し， 客観的に表現することは非常に困難である。この中で色 変化が最す判定並びに表現し易いので，前報ては「蒸気 量は，茶葉色の変化でみれば，ある一定量の蒸気量をで は茶葉の表裹の色合い近似に影響を与克るが，しかし一 定量以上になると蒸熱程度には注とんど関係しない。」 ことなどについて報告した。

本報では，蒸熱時間と茶葉色の関係について検討した 結果, 茶葉色の変化程度からみて, 蒸熱時關は蒸熱程度 に非常に関係が樑いこと，また蒸熱程度判定の一手法と なり得ると思われることなどが解ったので報告する。

\section{2 材料及び方法}

2.1 供 試材 料

供試原料は表 1に示すように，1983年及び1984年に福
岡県農業総合試験場茶業指導所のほ場で標準的に栽培管 理・生産されたやぶきたの生葉である。

この供試原料を宮村式の $250 \mathrm{~K}$ 型全自動送帯式蒸機で, 蒸熱時間を表 2 の上万に変えて苲熱条件の異なる蒸熱葉 (冷却葉) を各々 $6 \mathrm{~kg}$ 作成する。そして，この蒸熱葉か ら無作為に20本の新茅を抽出して供試材料とした。

\section{2 茶葉色の測定方法}

前報と同じ方法で行った。

\section{3 結果及び考察}

\section{1 表面色と裹面色の関係}

1 回の試験につき20枚ずつ合計60枚の生葉及び各条件 別蒸葉の表面と裹面の測色值を平均して表 3 に示した。 また，この数值を使用し表面色と袈面色の相違を色差と して計算し，同じく表 3 に示した。さらに結果について は省略するが，各20枚の実測值を用い生葉及び蒸葉の表 面と裹面の測色値について, 各項目別に $\mathrm{t}$ 分布に上る平 均に関する有意性の检定を行った。

生葉では前報と同じく表裹の色が明らか炕異なった。

蒸葉においては原料による差が幾分みられたが，蒸熱 条件の違いによる差は特になく，表裹の色差は $0.42 〜$

表 1 供試 原料

\begin{tabular}{|c|c|c|c|c|c|c|c|}
\hline 試 & 日 & 品種名 & 摘採日 & 摘採方法 & 出開度 & 百芽重 & 含 水 率 \\
\hline 1983 & 年 5 月 5 日 & やぶきた & 5 月 4 日 & 機械摘み & 57.96 & $\begin{array}{r}\mathrm{g} \\
69.6\end{array}$ & $350.1(77.8)$ \\
\hline 1983 & 年 5 月 7 日 & $"$ & 5 月 7 日 & " & 36.9 & 89.6 & $352.3(77.9)$ \\
\hline 1984 & 年 5 月 9 日 & $"$ & 5 月9日 & 両手摘み & 16.8 & 32.6 & $306.7(75.4)$ \\
\hline
\end{tabular}

注：百芽重・含水率は試験日に測定し，含水率の（）内は湿量基準。 
表 2 試 覻 構 成

\begin{tabular}{l|llllllll} 
蒸 熱 時間 sec & 0 & 15 & 30 & 40 & 50 & 60 & 90 & 150
\end{tabular} 蒸気量 目盛 $(\mathrm{kg} / \mathrm{h}) \mid 035(83) "$ " " " "

注：1） 0-0は生望。

2）蒸気量は宮村式流量計での目盛で，（）内 はカワサキ流量計への換算值 $(\mathrm{kg} / \mathrm{h})$ 。
0.62 の範囲であった。参考に NBS 単位(表 4 ) と，これは “差がわずか沉わかる”程度の差となり，汪 湾色合いが近似する傾向であった。

蒸葉測色值を項目別にみると，各項目とも茶葉間の変 動が大き表撉閒に有意差は認められなかったが，次の 上5な傾向が双られた。L及び、值は，表面が董面より

表 3 測色檤並びに表面と裹䤄の色差

\begin{tabular}{|c|c|c|c|c|c|c|c|c|c|c|c|}
\hline \multirow{2}{*}{$\begin{array}{r}\text { 蒸熱時間 } \\
\text { sec }\end{array}$} & \multicolumn{2}{|c|}{ 表 面 } & \multicolumn{2}{|c|}{ 測＼cjkstart色 } & \multirow{2}{*}{$\begin{array}{l}\text { 値 } \\
\sqrt{\mathrm{a}^{2}+\mathrm{b}^{2}}\end{array}$} & 表面と裹面 & \multicolumn{2}{|r|}{ 襄 面 } & \multicolumn{2}{|c|}{ 測＼cjkstart色 } & \multirow{2}{*}{$\begin{array}{l}\text { 值 } \\
\sqrt{\mathbf{a}^{2}+\mathbf{b}^{2}}\end{array}$} \\
\hline & $\mathrm{L}$ & $\mathbf{a}$ & b & $\mathrm{b} / \mathrm{a}$ & & の色 差 & $\mathrm{L}$ & a & b & $\mathrm{b} / \mathrm{a}$ & \\
\hline 0 & 31.6 & -7.5 & 11.2 & -1.50 & 13.54 & 6.27 & 37.4 & -8.1 & 13.5 & -1.68 & 15.74 \\
\hline 15 & 40.2 & -10.8 & 14.5 & -1.35 & 18.01 & 0.59 & 39.7 & -10.9 & 14.2 & -1.31 & 7.86 \\
\hline 30 & 39.6 & -10.2 & 14.3 & -1.41 & 17.54 & 0.54 & 39.2 & -10.4 & 14.0 & -1.36 & 17.45 \\
\hline 40 & 39.5 & -9.8 & 14.3 & -1.46 & $17 \quad 33$ & 0.62 & 39.0 & -10.0 & 14.0 & -1.41 & 17.25 \\
\hline 50 & 39.4 & -9.3 & 14.2 & -1.54 & 17.02 & 0.42 & 39.1 & -9.6 & 14.2 & -1.49 & 17.17 \\
\hline 60 & 39.5 & -8.8 & 14.2 & -1.63 & 16.67 & 0.55 & 39.0 & -9.0 & 14.1 & -1.57 & 16.74 \\
\hline 90 & 39.0 & -7.7 & 13.9 & -1.81 & 15.92 & 0.46 & 38.8 & -8.1 & 14.0 & -1.74 & 16.13 \\
\hline 150 & 39.3 & -6.3 & 13.9 & -2.24 & 15.30 & 0.54 & 39.1 & -6.7 & 14.2 & -2.14 & 15.73 \\
\hline
\end{tabular}

表 4 NBS単位と感覚値の関係

\begin{tabular}{|c|c|}
\hline NBS単位 & 覚 \\
\hline $0 \sim 0.2$ & 善がわからない \\
\hline $0.2 \sim 0.5$ & 差が極めてわずかにわかる \\
\hline $0.5 \sim 1.5$ & 差がわずかにわかる \\
\hline $1.5 \sim 3.0$ & 差がかなりある \\
\hline $3.0 \sim 6.0$ & 差が著しい \\
\hline $6.0 \sim 12.0$ & 差が極めて著しい \\
\hline 12以上 & まったく異なった色と見なされる \\
\hline
\end{tabular}

やや大きく，蒸熱時間が長くなるにつれて表面と襄面の

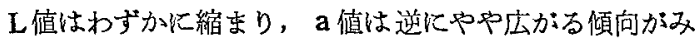
られた。b及び $\sqrt{a^{2}+b^{2}}$ 値は, 表面の変化が大きく て蓑面の方が一時小さくなるが，50・60秒付近で表龒の 値が逆転する見象がみられ，ての後は再び生葉と同様に 異面が大きくなる傾向がみられた。b/a 值は，生葉では 表面が大きくて表襄の差も大きいが，蔡葉では逆㜔面 が大きい傾问であり，また蒸熱時間が長くなるにつれて， わずか炕表寰の差が広がる傾向が双られた。

\section{2 生葉と蒸葉の関係}

3 回の試験の平均值を使っての生葉と蒸葉並び沉蒸熱 条件を糞にする蒸葉問の色差は表 5 亿示した。さらに各 々20枚の実測値を使って, 生葉と蒸葉の測色値について

表 5 蒸熱時間を異几する蒸葉の色差

\begin{tabular}{|c|c|c|c|c|c|c|c|c|c|c|c|c|c|c|c|c|}
\hline \multirow{2}{*}{ 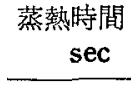 } & \multicolumn{3}{|c|}{ 表 } & \multirow[b]{2}{*}{40} & \multirow[b]{2}{*}{50} & \multirow[b]{2}{*}{60} & \multicolumn{2}{|l|}{ 面 } & \multicolumn{3}{|c|}{ 裏 } & \multirow[b]{2}{*}{40} & \multirow[b]{2}{*}{50} & \multicolumn{3}{|c|}{ 面 } \\
\hline & 0 & 15 & 30 & & & & 90 & 150 & 0 & 15 & 30 & & & 60 & 90 & 150 \\
\hline 0 & - & & & & & & & & - & & & & & & & \\
\hline 15 & 9.78 & - & & & & & & & 3.69 & - & & & & & & \\
\hline 30 & 8.99 & 0.87 & - & & & & & & 2.96 & 0.73 & - & & & & & \\
\hline 40 & 8.79 & 1.24 & 0.41 & - & & & & & 2.53 & 1.16 & 0.45 & - & & & & \\
\hline 50 & 8.55 & 1.73 & 0.93 & 0.52 & - & & & & 2.37 & 1.59 & 0.83 & 0.46 & - & & & \\
\hline 60 & 8.55 & 2.14 & 1.41 & 1.00 & 0.51 & - & & & 1.93 & 2.03 & 1.42 & 1.00 & 0.62 & - & & \\
\hline 90 & 7.88 & 3.38 & 2.60 & 2.20 & 1.68 & 1.24 & - & & 1.49 & 2.95 & 2.33 & 1.91 & 1.54 & 0.93 & - & \\
\hline 150 & 8.25 & 4.63 & 3.93 & 3.53 & 3.02 & 2.53 & 1.43 & - & 2.31 & 4.24 & 3.71 & 3.01 & 2.90 & 2.30 & 1.45 & - \\
\hline
\end{tabular}


各項目別・蒸熱条件別に， $\mathrm{t}$ 分有に上る平均に関する有 意性の検定を行ったが，絬果は省略する。

生葉と蒸葉の色差は, 表面色では 8.7 程度あり, “極 めて差が著しく”一目で区別ができたが, 敦面色の色差 は 2.5 程度で表面色に比べれば相当接近していた。

前報です報告したように，生葉を蒸熱すると亱面色の 変化が少ない割化表面色が大る変化するため, 表面色 が裹面色任近付く形で表亭の色合いが近似する。特に表 面の明度及び彩度の変化が大きいのでこような状態に なると考えられるが，今回の蒸熱時間の差による条件下 では，色相の大幅な变化が認められた。これは蒸気星の 差に上る条件下ではみられない現象であった。

影度の変化す大きいが色相の变化の方が大く活活直 線的に変化するので，蒸熱程度を色で表現でるるすれ ば色相の変化程度で表現でるのではないかと考える。 例觉ば一般的な経験によると, 生葉の色より蒸葉の色か わずかに緑みを増与時点を標準的な蒸熱程度とし，標準 的な蒸熱時間は40秒程度とされている。従っでこれを 因 1 で示す色相の変化に適用して考兄てみると，蒸葉表 面の b/a 值が生菜表面のb/a 值より大き過ざれば「蒸 しが若い(若蒸し)」, 同程度の值であれば「適度な蒸し (慗準蒸し)」, 小さくなるにつれて「蒸しが染くなる (樑蒸し)」と表現でるのではないかと考える。さら に供試した生荣の色合い・形啠等は異なるよ5だが，参 考まで岩浅らが開発した「茶葉蒸葉標準スケール」を 福岡と京都, 三重の各試験場が 日本電色工業製の色差計
で測定した値を表6に示した。

表 $60 \mathrm{~b} / \mathbf{a}$ 値は40秒付近を境として，蒸熱時間が短い 場合は生葉（0）より大きく, 長い場合は生葉より小さ くなり, 今回の試験と同様な傾向を示している。今回

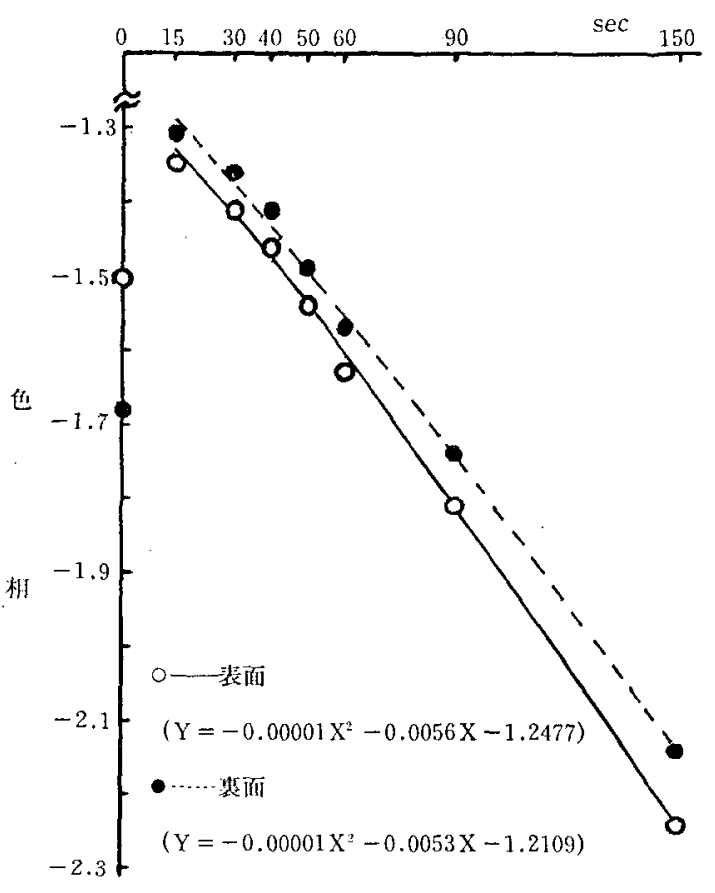

図 1 蒸熱時間々蒸葉の色相（b/a）との関係 表 6 「茶葉蒸葉標準スケール」の测色值

\begin{tabular}{|c|c|c|c|c|c|c|c|c|}
\hline 項目 & $\begin{array}{l}\text { 測定 } \\
\text { 場所 }\end{array}$ & 0 & $\begin{array}{l}\text { 蒸 } \\
20\end{array}$ & 熱 & $\begin{array}{c}\text { 時 } \\
40\end{array}$ & $\begin{array}{c}\text { 間 } \\
60\end{array}$ & $\begin{array}{c}\text { (sec) } \\
80\end{array}$ & 100 \\
\hline \multirow{3}{*}{ L } & $\mathrm{A}$ & 33.4 & 36.9 & 37.2 & 37.9 & 36.5 & 35.4 & 34.6 \\
\hline & B & 33.8 & 37.3 & 37.4 & 38.1 & 37.0 & 35.9 & 34.9 \\
\hline & $\mathrm{C}$ & 32.8 & 36.4 & 36.7 & 37.3 & 36.1 & 35.0 & 34.0 \\
\hline \multirow{3}{*}{ a } & A & -11.1 & -10.9 & -11.0 & -10.7 & -10.5 & -8.5 & -7.8 \\
\hline & B & -14.0 & -14.0 & -13.9 & -13.9 & -13.2 & -11.3 & -10.6 \\
\hline & C & -11.4 & -11.3 & -11.1 & -10.9 & -10.4 & -8.5 & -7.9 \\
\hline \multirow{3}{*}{ b } & A & 16.5 & 15.3 & 15.7 & 16.0 & 15.9 & 15.2 & 14.8 \\
\hline & B & 17.2 & 16.4 & 16.5 & 16.8 & 16.6 & 15.8 & 15.5 \\
\hline & C & 16.5 & 15.5 & 15.5 & 16.0 & 15.7 & 15.0 & 14.1 \\
\hline \multirow{3}{*}{$b / a$} & A & -1.49 & -1.40 & -1.43 & -1.50 & -1.51 & -1.79 & -1.90 \\
\hline & B & -1.23 & -1.17 & -1.18 & -1.21 & -1.26 & -1.40 & -1.46 \\
\hline & C & -1.45 & -1.37 & -1.40 & -1.47 & -1.51 & -1.76 & -1.79 \\
\hline
\end{tabular}

注：1）茶葉蒸葉標準スケールは，農林水産省茶業試験場が1978年に開発したもので，それぞれの場所がテス ト用に貸与されたものを使用した。

2) 測定は福岡県農総試茶業指導所が ND-504DE 型色差計で1979年 4 月28日, 京都府茶業研究所がND101DP型色差計て1979年 4 月25日，及び三重県農技センター茶業センターが CS-K6B 型色差計を使用 して，1979年 4 月17日に照射面積 $\phi 10 \mathrm{~mm}$ で測定した。

$\dagger$ 岩浅 潔, 茫生 蹕, 島善一郎, 平并敏决: 茶技協講要 Feb. 1978, 28. 
の試験では45秒付近が境になっている。これは「茶葉蒸 葉標準スケール」が二・三番茶期の $2 \cdot 3$ 葉目を使用し たのに対し，今回は一番茶期の 2 葉目を使用したこと等 により，原料の違いによる蒸気熱の浸透具合などに差が あったためと考えられる。同様な傾向を示しても，原料 に応じて境が異なることは，蒸しが「きき易いりとか「き き難い」と言われる原料差に関係なく利用できることを 明確に示していることになる。このように，生葉表面と 蒸葉表面の b/a 值, すなわち色相の変化を比較するこ とは蒸熱程度判定の大きな一手法となり得ると若光る。

蒸集測色値は項目別棌生葉測色值と比較検討すると次 のようであった。 L值は表面の変化が特に大きく，表亭 ともに生葉の襄面よりやや大きい值となった。a 值は蒸 熱されることによって生葉の時より一度小さくなるが， その後は蒸熱時間が長くなるにつれて大きくなり，緑色 が薄れていく傾向であった。 b 值㳖表裹の差が非常に小 さくなるとともに，表裹とも生葉の裏面よりやや大きい 值となった。すなわち表面は $1 \%$ 水準で有意差が認めら れ大きく変化していることを示しているが，褧面には有 意差が認められなかった。 b / a 值は生葉より一度大きく なるか，蒸熱時間が長くなるにつれて小さくなり，黄色 方向になる傾向が認められた。 $\sqrt{\mathrm{a}^{2}+\mathrm{b}^{2}}$ 值は表裹とも 生葉より大きい值を示し，あざやかになる傾向が認めら れた。

\section{3 蒸葉間の関係}

蒸葉問の色差は表 5 亿示すよ 5 亿表面色で0.41 4. 63, 裹面色で 0.45 4.24 と“差が極めてわずかにわかる”程 度から“差が著しい”の範团となり, 前報の蒸気量の差 に比べて非常に大きい值である。色差が最も大きいのは 表裏々す15秒蒸葉と 150 秒蒸葉の間で，その差はそれぞ れ4.63と4.24で明らが炕別がつくるのであった。逆に， 色差が最も小さいのは表裹とも30秒蒸葉と40秒蒸葉の閒 であった。次いて40秒蒸葉と50秒蒸葉の差が小さく，50 秒蒸葉々60秒蒸葉の差す小さい傾向であった。

網胴回転擋拌式蒸機で一般的に使用されている30秒か

表 7 蒸熟時間と蒸葉測色値との相関関係

\begin{tabular}{|c|c|c|c|c|c|}
\hline 項 & 目 & \multicolumn{2}{|c|}{$\begin{array}{l}\text { 表 面湘 色 值 } \\
11 \text { 次 } 2 \text { 次 } \\
\end{array}$} & \multicolumn{2}{|c|}{$\begin{array}{l}\text { 裏面测 } \begin{array}{l}\text { 色值 } \\
1 \text { 次 } 2\end{array} \text { 次 } \\
\end{array}$} \\
\hline & $\mathrm{L}$ & -0.668 & $0.940^{* *}$ & -0.488 & $0.933^{* *}$ \\
\hline & a & $+0.988^{* *}$ & $0.999^{* *}$ & $+0.989^{* *}$ & $0.998^{* *}$ \\
\hline & $\mathrm{b}$ & $-0.908^{* *}$ & $0.974^{* *}$ & +0.202 & 0.527 \\
\hline & $\mathrm{b} / \mathrm{a}$ & $-0.998^{* *}$ & $0.999^{* *}$ & $-0.998^{* *}$ & $0.999 * *$ \\
\hline$\sqrt{ }$ & $\overline{a^{2}+b^{2}}$ & $-0.973^{* *}$ & $0.997^{* *}$ & $-0.963^{* *}$ & $0.993^{* *}$ \\
\hline
\end{tabular}

注：1） 数值は相関係数（相関比）。

2）**は1\%の有意水準を示す。
ら60秒の間では“差がわずかにわかる”範囲までに収ま ってしまった。しかしこの笵囲内です蒸熱時間が長くな るにつれて色差が大きくなる傾向が認められ，蒸熱時間 の長短が蒸葉色の変化には関係深いことが認められた。

蒸熱時間と蒸葉色との相関関係については表 7 K示し ている。また，色相・明度・彩度と蒸熱時間との二次回

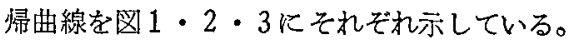

蒸葉測色値を項目別に検討してみると，L值は15秒か ら90秒付近までは徐々に低下しその後かずが上昇する が，その差は小さく特に30秒から60秒までは汪とんど変 化しなかった（図 2)。a 值は，15秒から60秒付近をで

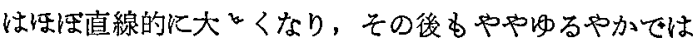

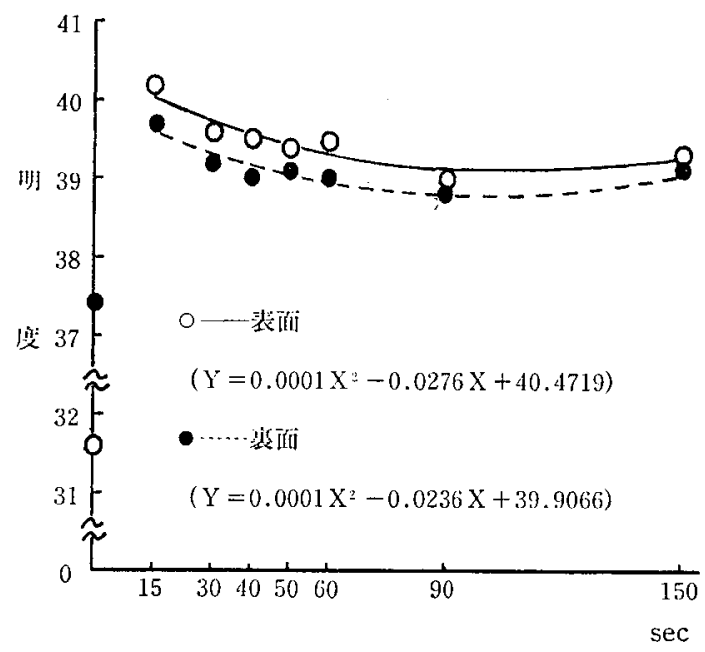

図 2 蒸熱時間と蒸葉の明度へL）との関係

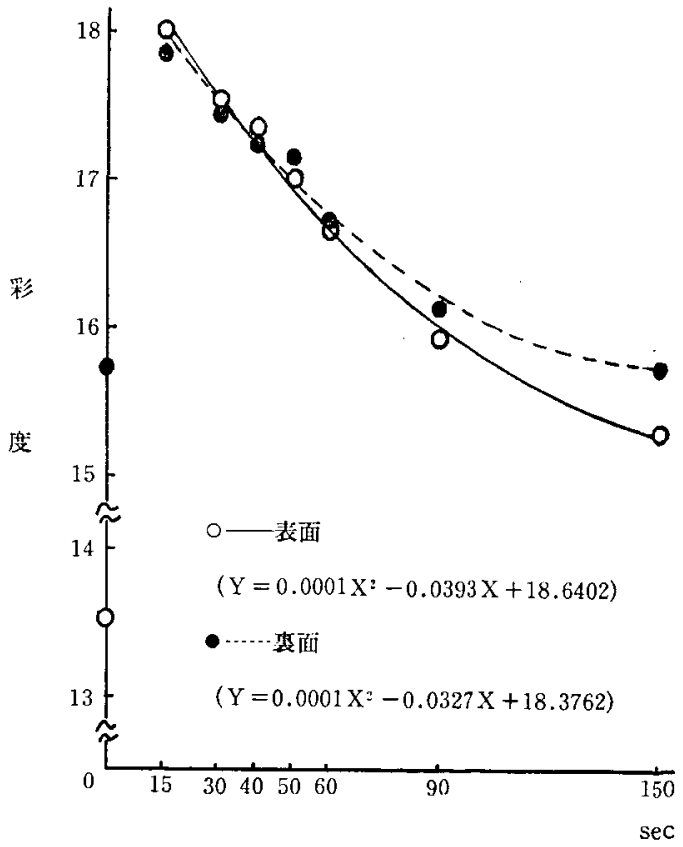

困 3 蒸熱時間と蒸葉の彩度 $\sqrt{\mathrm{a}^{2}+\mathrm{b}^{2}}$ との関係 
あるが大きくなる。すなわち, 蒸熱時間が長くなるにつ れて緑みが薄れていく傾向が認められた。これは，高温 の持続によってクロロフィルが変化していくためだと考 えられる。b值は, 聂面の変化は認められなかったが, 表面では蒸熱時間が長くなるにつれてわずかに小さくな る傾向であった。しかし，上值同様に30〜60秘間は非と しど変化しなかった。

$\mathrm{b} / \mathrm{a}$ 值は, 游漂直線的に小さくなり, 蒸熱㭙間が長 くなるにつれて緑色系から黄色系方向へと変化すること が認められた（図 1)。荒茶に打ける色相 (b/a), ク口 ロフィルのフェオフィチンヘの変化率及び品質（色沢） について表8に示した。この表から，蒸葉での色相は製 品での色相や色沢評点と相関が非常に高いことが解る。 このことからも，蒸葉の色相は蒸熱程度判定の一つの大 きな目安になると推测できるので，今後この面を劷練に 検琂する必要がある5。

$\sqrt{\mathrm{a}^{2}+\mathrm{b}^{2}}$ 值は15秒から60秒付近まては惊直線的保 小さくなり，その後も小さくなるがややゆるやかなカー ブになる傾向が認められた。また，蒸熱時間が長くなる と表裹の值が50秒付近で逆転し，生葉同様表面が小さく なる傾向が文られた（図了）。

丧 8 荒茶の色相, 品質等

（1984年 5 月 9 日試験行）

\begin{tabular}{|c|c|c|c|c|}
\hline 蒸熱時間 & $\begin{array}{l}\text { 色 相 } \\
(\mathbf{b} / \mathbf{a})\end{array}$ & 変化率 & $\begin{array}{l}\text { 製 茶 } \\
\text { 色沢 }\end{array}$ & $\begin{array}{l}\text { 品 質 } \\
\text { 品質合計 }\end{array}$ \\
\hline $\begin{array}{l}\text { sec } \\
15\end{array}$ & -1.85 & $21.46^{\%}$ & 15.0 & 72.5 \\
\hline 30 & -1.90 & 25.25 & 14.5 & 73.5 \\
\hline 40 & -1.93 & 25.73 & 14.0 & 74.5 \\
\hline 50 & -2.08 & 27.77 & 13.5 & 72.5 \\
\hline 60 & -2.17 & 28.17 & 13.5 & 71.5 \\
\hline 90 & -2.49 & 33.32 & $\begin{array}{c}\text { やや赤み } \\
12.5\end{array}$ & $\begin{array}{c}\text { やや深蒸 } \\
\text { L葻 } \\
65.0\end{array}$ \\
\hline 150 & -3.09 & 39.49 & $\begin{array}{c}\text { 黄褐色み } \\
11.0\end{array}$ & $\begin{array}{c}\text { 深蒸L風 } \\
60.5\end{array}$ \\
\hline
\end{tabular}

注：1） 変化率とはクロロフィルのフェオフィチン への変化率のことで島津製作所製のuv-11002型比色計を使用。

2）製茶品質は普通審查法による。

\section{4 摘 要}

蒸熱時間の長短が茶葉色の变化にどの上うな影響を与 えるか，生葉及び蒸葉の第 2 葉目を色差計で測定した。 その結果は次のと抲りであった。

1）明度は，蒸熱時間が長くなるにつれて極くわずか つつ低下した。

2）色相は，蒸熱時間が長くなるにつれてほ活直線的 に緑色系から黄色系へと変化した。

3）彩度は，蒸熱時間が長くなるにつれて徐々に低下 ししかも表裏の值が途中で逆転した。

4) 蒸熱程度は蒸熱時間の長短に大きな影響を受け た。

5）生葉表面の色相と蒸葉表面の色相から, 蒸熱程度 が推定できた。

最後に，取りまとめにあたり御指導頂いた農林水産省 茶業試駼場の岩浅 潔博士及び当所の坂田寿生所長に深 甚なる謝意を表します。

\section{5 参考文献}

1）大森 毫, 中村晋一郎，渡辺敏朗：茶研報， No. 63, 24 29 (1986).

2）日本繊維センター編：纎維試験法のすべて（基礎 編), pp. 241 (1978).

3）岩浅 眔，農林水産技術会議事務局編：新しい技 術, No. 16, pp. 141 145 (1978).

\section{Summary}

Effecf of steaming time on the color of a steamed tea leaf was examined. Hunter's Lab values were measured on a color-difference meter, and $L, b / a$ and $\sqrt{a^{2}+b^{2}}$ were used as measures of lightness, hue and chroma, respectively.

As steaming was prolonged, the hue of a steamed leaf changed from greenish to yellowish, its lightness was slightly lowered and its chroma also fell down. The degree of leaf-steaming was much influenced by the steaming time and coind be estimated in terms of the hues in the surface of a fresh and steamed leaf.

(Sep. 30, 1985) 